\title{
The effects of treaty legality and domestic institutional hurdles on environmental treaty ratification
}

\author{
Gabriele Spilker • Vally Koubi
}

\begin{abstract}
We study the effects of treaty design and domestic institutional hurdles on the ratification behavior of states with respect to multilateral environmental agreements (MEAs). Specifically, we examine whether (1) strong legality mandated by a treaty such as precisely stated obligations, strong monitoring/enforcement mechanisms, and dispute resolution procedures, and (2) high domestic constitutional hurdles such as requirements for explicit legislative approval deter countries from ratifying a treaty. To test our theoretical claim, we use a new time-series-cross-sectional dataset that includes information on the ratification behavior of 162 countries with respect to 220 MEAs in 1950-2000. We find that treaties that are characterized as 'hard' indeed deter ratification. Furthermore, explicit legislative approval requiring supermajority also makes treaty ratification less likely.
\end{abstract}

Keywords Multilateral environmental agreements · Ratification ·

'Hard' treaty · 'Soft' treaty · Legislative approval

G. Spilker

Department of Political Science and Sociology, University of Salzburg, Rudolfskai 42, 5020 Salzburg, Austria

e-mail: gabriele.spilker@sbg.ac.at

G. Spilker · V. Koubi ( $₫)$

Center for Comparative and International Studies (CIS) and Institute for Environmental Decisions (IED), ETH Zurich, Haldeneggsteig 4, IFW C43.2, 8092 Zurich, Switzerland

e-mail: koubi@ir.gess.ethz.ch

V. Koubi

Department of Economics, University of Bern, Schanzeneckstrasse 1, A318, 3001 Bern, Switzerland 


\section{Introduction}

Some of the most important environmental problems such as climate change, ozone depletion, air and marine pollution have been the focus of intense negotiations at the international level over the past two decades. In the absence of supra-national institutions, voluntary cooperation between countries in multilateral environmental agreements (MEAs) is probably the only way to solve some of the most pressing environmental problems. However, cooperation on multilateral environmental issues is often hard to achieve because of incentives to free ride (Barrett 1994; Finus 2001). Barrett (1994) for example shows that a multilateral environmental agreement made of more than three countries is unstable since most countries would prefer to do nothing and rely on the efforts made by other countries. For environmental problems involving many countries, it therefore seems unlikely that all countries will participate in a multilateral environmental agreement.

The stylized facts, however, are in sharp contrast to theoretical prediction in that there exist many environmental agreements with a large number of participating countries such as the Kyoto and Montreal Protocols. Moreover, given the observed variation in participation in MEAs despite the generally high incentives to free ride, it is important to better understand the factors that motivate countries to enter into legally binding commitments at the international level. Most of the existing literature on the ratification of international agreements concentrates on the formal process of designing and establishing international agreements (Koremenos et al. 2001; Abbott et al. 2000; Abbott and Snidal 2000), on the effects of ratification for international cooperation (Martin 2000; Rosendorff and Milner 2001; Simmons 2009), and on the impact of political and economic globalization, networks, environmental vulnerability, political regimes, and environmental groups on ratification behavior (Beron et al. 2003; Congleton 1992; Fredriksson and Gaston 2000; Fredriksson and Ujhelyi 2006; Neumayer 2002a, b; Roberts et al. 2004; von Stein 2008; Simmons 2009; Bernauer et al. 2010; Perrin and Bernauer 2010; Bernauer et al. 2013a, b; Subramanian and Urpelainen 2013).

Although this literature offers important insights on the ratification dynamics underlying multilateral environmental agreements, there is still room for improvements (Wangler et al. 2013). For instance, most studies are based on individual treaties or on very small samples of multilateral environmental treaties, ${ }^{1}$ their empirical design is cross-sectional ${ }^{2}$ and thus mostly ignores potentially important temporal dynamics, and they do not take into account treaty design characteristics. ${ }^{3}$

In this paper, we build and expand on the existing work in three directions: First, we examine closely the impact of treaty legality and domestic institutional hurdles on ratification behavior alongside the already more extensively studied determinants of cooperation, such as interdependency effects, trade openness, national income, and regime type. We argue that treaty legality as well as domestic institutional hurdles is important determinants of a government's propensity to ratify a treaty. Treaty legality refers to whether a treaty is considered to be a 'hard' or 'soft' treaty, which is a function of its design characteristics such as the precision of obligation, the existence of strong monitoring and enforcement mechanisms, and dispute resolution procedures. Domestic institutional hurdles refer to the constitutional requirements for treaty ratification. Examining these particular conditions under which countries ratify multilateral treaties while focusing on

\footnotetext{
${ }^{1}$ Exceptions are Bernauer et al. (2010) and Roberts et al. (2004).

${ }^{2}$ With the exception of von Stein (2008), Bernauer et al. (2010), and Perrin and Bernauer (2010).

${ }^{3}$ Exceptions are von Stein (2008) and Bernauer et al. (2013a).
} 
environmental treaties may contribute not only to a better understanding of when countries ratify an agreement but also to a more general understanding of countries' perceptions and behavior regarding the state of their environment.

Second, we test our arguments on a new dataset that includes information on ratification behavior of 160 countries as well as treaty characteristics with respect to 220 multilateral environmental agreements in the time period 1950-2000. And third, we use an empirical design (treaty-country dyads over time) that permits analysis of both treaty-related as well as country-related driving forces of international environmental cooperation.

We find that, in line with our theoretical argumentation, treaties that can be characterized as 'hard' indeed deter ratification. Hence, treaties that contain specific obligations, provide clear monitoring and enforcement mechanisms, and have explicit dispute settlement procedures are more likely to impinge upon state sovereignty and thus are less likely to be ratified. Furthermore, countries with constitutions that ask for explicit legislative approval in the form of a supermajority are also less likely to ratify MEAs because the required consent of a great number of legislators with divergent preferences leads to a policy stasis and consequently to ratification failure.

The remainder of the article proceeds as follows. We first discuss the theoretical arguments on treaty legality and domestic institutional hurdles on environment treaty ratification and state the hypotheses to be tested. The subsequent section defines the variables and research design, and presents the results. The article concludes with a discussion of the main findings of our paper and venues for future research.

\section{Theory and hypotheses}

\subsection{Treaty legality}

Scholars of international law and international institutions have long been interested in examining the questions why and when states choose to create or avoid international agreements. The short answer is that only those countries that share the goals of an agreement will enter into this agreement and will decide on the degree of its legality on the basis of credibility and flexibility considerations. Some scholars argue that states prefer informal ('soft' law or pledges) over formal agreements because these informal agreements make fewer demands on governments and thus allow states to adjust or exit these agreements more easily under conditions of uncertainty (Koremenos 2001, 2005; Abbott and Snidal 2000; Simmons 2000; Downs et al. 1996). Others, however, posit that states choose to enter into legally binding agreements ('hard' law, contracts or treaties) in order to signal the seriousness of their intentions and enhance the credibility of their commitment by increasing the reputational costs of noncompliance (Guzman 2002; Lipson 1991).

While traditional international law scholars assume that 'legality is best understood as a binary, rather than a continuous attribute' (Raustiala 2005, 586), this binary view has in recent years gradually given way to notions of 'soft' law not only as non-legally binding agreements, but also as legally binding agreements that lack features deemed necessary for an agreement to be 'hard' law, such as precision of obligations and/or enforcement mechanisms (Raustiala 2005; Abbott et al. 2000; Abbott and Snidal 2000). Consequently, many scholars now accept that 'hard law' can vary significantly in substance and structure (Raustiala 2005; Guzman 2005). Substance refers to the precision of the agreement and the obligations imposed on the contracting parties by the agreement; and structure refers to provisions for monitoring and enforcing commitments as well as to a dispute resolution 
mechanism. Chinkin $(1989,851)$, for example, argues that 'the use of a treaty form does not of itself ensure a hard obligation. ... If a treaty is to be regarded as 'hard,' it must be precisely worded and specify the exact obligations undertaken or the rights granted.' ${ }^{4}$

A cursory look at the texts of international treaties reveals that treaties do vary to a great extent with regard to precision of obligations as well as to compliance mechanisms set forth therein. Some treaties do not state any specific obligations that countries are required to satisfy, whereas others explicitly state such obligations. For example, the Vienna Ozone Convention and the UN Framework Convention on Climate Change (FCCC) do not impose any or only minor obligations on participant countries. On the other hand, the Montreal Protocol and the Kyoto Protocol contain clearly specified obligations such as the phasing out of numerous substances believed to be responsible for ozone depletion and $\mathrm{CO}_{2}$ emissions reductions, respectively.

A treaty that is regarded as 'hard' has precisely stated obligations and delegates authority to implement and interpret these obligations, and thus, it is perceived as more credible and can induce states to find ways to reach the policy goals they agreed on (Guzman 2002). In addition, such a treaty is more likely to enhance the credibility of the commitment by increasing the reputational costs a state will incur if it reneges on its commitment (Simmons 1993, 2000; Guzman 2002). Finally, a 'hard' treaty can reduce the occurrence of incomplete contracting by reducing the transaction costs of application of the law and by decreasing post-agreement costs such as management and enforcement (Abbott and Snidal 2000; Smith 2000; Rosendorff 2005; Chayes and Chayes 1993).

A 'hard' treaty, however, has also its pitfalls. Because of its binding obligations and the delegation of authority to a supranational body, it decreases a state's sovereignty, that is, its freedom to act in any way the state deems to be appropriate to maximize its self-interest. Downs et al. (1996) and Raustiala (2005), for instance, argue that countries are less likely to participate in agreements that require substantive commitments on their part such as to reduce pollution levels, refrain from producing nuclear weapons, or respect human rights. Downs et al. also maintain that states avoid agreements that have strong enforcement mechanisms. Similarly, Abbott and Snidal (2000) note that delegation of monitoring authority makes it more difficult for states to interpret the respective agreement in a selfserving or biased manner. This makes states reluctant to delegate authority for the purposes of monitoring and enforcement as well as dispute resolution. Several studies provide empirical evidence that agreements that include strong enforcement mechanisms and/or require substantive commitments are less likely to be ratified by a large number of countries (Hathaway 2007; Goodliffe and Hawkins 2006; Cole 2005, 2009; Bernauer et al. 2013a). Yamagata et al. (2013), for instance, show that Annex I countries were less likely to ratify the Kyoto Protocol compared to Annex II countries because the obligations they were asked to take up. Thus, one should expect 'hard' treaties to be more difficult to ratify.

A 'soft' treaty, on the other hand, lacks precisely stated obligations and/or monitoring, enforcement and dispute resolution mechanism. Consequently, such a treaty gives states the opportunity to adapt commitments to their country's particular needs and allows them a range of discretion and flexibility in interpreting and implementing particular commitments. A 'soft' treaty thus allows states to remain sovereign. This flexibility allows states

\footnotetext{
${ }^{4}$ In this paper, we focus only on treaties, which, according to the Vienna Convention on the Law of Treaties, constitute 'hard' law. Furthermore, we use the term 'hard' treaty to indicate any treaty that imposes well-defined obligations, and create procedures to monitor and enforce these obligations as well as dispute resolution mechanisms; and 'soft' treaty to denote any treaty that is deficient in precision of obligations and/ or monitoring and enforcement measures, and dispute resolution mechanisms.
} 
to respond to unanticipated shocks as well as to special domestic circumstances without compromising existing institutional arrangements (Koremenos 2001, 2005; Koremenos et al. 2001; Rosendorff and Milner 2001; Boockmann and Thurner 2006; von Stein 2008; Böhmelt and Pilster 2010). Koremenos (2001, 2005), for instance, notes that the participation of certain risk-averse states in treaties on several issue areas (economic, human rights, environmental, and security) was mainly due to the treaties' flexibility provisions. In addition to giving states flexibility in implementation, 'soft' treaties can level the playing field between weak and strong states and allow for compromise over time.

While a 'soft' treaty facilitates compromise and avoids some of the costs associated with 'hard' treaties, it is often viewed as 'window dressing' because it lacks credibility. In addition, the adaptability of rules and obligations postulated in a 'soft' treaty can also give states the opportunity to shirk, leading thus to reduced forms of actual cooperation. Nevertheless, despite its pitfalls/disadvantages, a 'soft' treaty on average could be more attractive to national governments because of its lower contracting cost and the fewer limits on national sovereignty.

In situations where the issues are unclear and the outcomes are uncertain, international agreements may be very important for avoiding Pareto deficient outcomes, but states may hesitate of getting tied into agreements that pose great threats and constrains to their national sovereignty. Given that a 'hard' treaty can tie a state into an agreement that reduces its autonomy of action, we expect 'hard' multilateral environmental treaties to be less attractive in terms of ratification relative to the ones characterized as 'soft' treaties.

H1 The harder the requirements of a multilateral environmental treaty are, the lower the probability of its ratification.

\subsection{Domestic institutional hurdles}

The decision to become a party to a treaty is often an executive decision meaning that the incumbent government decides to be a party to a treaty and consequently a representative of the government signs the treaty. A major challenge governments face after signing a MEA is whether they will be successful in ratifying it. Ratification occurs when the national legislature approves the principles set forth in a treaty. Given that countries have exhibited widely different ratification behavior, it is important to examine more closely how domestic political institutions affect this ratification behavior.

Domestic political institutions determine how political control is distributed among the actors responsible for policy making. The decision to become a party to a treaty is the act of a government via two stages: negotiation and signature of the treaty by the executive branch, and ratification of the treaty by the legislative branch (Barrett 1998, 2006). Signing of a treaty, thus, is to indicate only the intention of the government to become a party to a treaty. Given that almost all multilateral treaties have ratification clauses it seems that the process of ratification provides time or a second thought for a country as to whether or not it should become a party to a treaty. That is, if the provisions of a treaty are too burdensome or onerous, a country's decision makers may finally decide not to become a party to this treaty despite the signature by its government representative.

Depending on the provisions of the constitution of a country, ratification may be either executed by the government itself (i.e., the executive branch) (Israel, Bangladesh, Libya) or by the legislature. When such an approval is required, constitutions usually specify not only whether the consent of one or both houses of the legislature is required but also the voting threshold (simple majority or supermajority) that is necessary to be reached by the 
legislature (Hathaway 2008). Consequently, in countries where the constitution does not provide for any additional ratification provisions, the executive can just go ahead and ratify the treaty she has signed. However, if legislative consent is required to ratify a treaty, an additional actor is involved in the ratification process, making the process more demanding. In addition, a high required voting threshold (majority versus supermajority) further complicates the ratification process. The main reason is that a greater number of veto players ${ }^{5}$ i.e., required legislators, with divergent preferences is more likely to lead to a policy stasis and consequently to ratification failure (Bang et al. 2012; Fredriksson et al. 2007; Tsebelis 2002; Rosendorff and Milner 2001).

Milner (1997), for instance, shows that ratification failure is most likely when domestic preferences are divergent and when domestic actors are asymmetrically informed. Milner and Rosendorff (1997) add that great internal divisions imply that legislatures are less likely to ratify international agreements, although this can to some degree also be used by negotiators to extract concessions. Finally, Fredriksson and Ujhelyi (2006) find that institutional arrangements with a greater number of veto players reduce the positive impact of environmental lobbying on the ratification probability. Hence, we expect ratification to be increasingly difficult as such requirements become more demanding to satisfy.

H2 The higher a country's formal, constitutional requirements for treaty ratification are, the lower the probability of ratification.

\section{Empirical analysis}

\subsection{Dependent variable and methodology}

We test the above hypotheses on a new panel dataset covering 160 countries' attitudes (ratification 6 : yes/no) toward 220 multilateral environmental treaties from 1950 to 2000. The dataset is based on the data used by Bernauer et al. (2010, 2013a). Following Bernauer et al. (2010), the unit of analysis is the treaty-country pair per year, which implies that each treaty enters the dataset at the moment when it becomes open for ratification and is then paired with all countries that are considered to be sovereign states at that time. Countries that come into being after a particular treaty has become open for ratification are paired with these older treaties once they gain independence. Hence, each observation consists of a particular treaty, a specific country that may or may not have ratified the treaty, and the year this action takes place. ${ }^{7}$ Each treaty-country pair stays in the dataset and is coded with a zero until the year when the respective country ratifies the treaty and the dependent variable then changes from zero to one. A treaty-country pair leaves the dataset in the year after the country has ratified the treaty. This approach allows us to include both country characteristics including legislative approval and treaty legality.

In our analysis of a country's ratification choice (yes/no), we follow the approach proposed by Carter and Signorino (2010), which views binary-time-series-cross-sectional

\footnotetext{
5 Veto players are individuals (president, prime minister) or collective political units (chambers of the legislature, government coalition members, political parties, an independent judiciary) whose approval is necessary for policy change and in our study for the ratification of an international environmental treaty.

6 The term 'ratification' indicates any form of binding commitment (as opposed to signature). Depending on the specific legal context, this commitment can also be expressed by adhesion, accession, etc.

7 Only in very rare circumstances does a country withdraw from a treaty it has already ratified. If this was the case, the particular country-treaty combination was reintegrated into the dataset.
} 
data as grouped duration data in which the interval of observing the data is fixed to 1 year. Hence, we use logit analysis and include time as well as its squared and cubic term ( $\mathrm{t}_{2} \mathrm{t}_{2}$, and $t_{3}$ ) to model temporal dependence. This approach is similar to a survival analysis, the difference being that the dependent variable in this framework is observed yearly, whereas many survival models are designed for continuous time. Furthermore, we cluster our standard errors by country. ${ }^{8}$

The data on treaty ratifications are based on the dataset by Bernauer et al. (2010) who retrieved the data from the environmental treaties dataset by the Center for International Earth Science Information Network (CIESIN) (2005) and Mitchell (2002). We re-coded the data to fit the particular format used for this analysis. Our dataset includes only those multilateral treaties that are in principle open for ratification to any country and deal with an environmental issue as their main purpose, resulting in a total of 220 treaties. $^{9}$

\subsection{Explanatory variables}

The two main explanatory variables are treaty legality (Hard treaty) and domestic constitutional hurdles (Formal, constitutional requirements). 'Hard' treaty is coded by means of content analysis of treaty texts. ${ }^{10}$ This variable is essentially coded as a binary variable indicating whether the treaty is 'hard' or 'soft.' We consider the three variables quantitative targets, monitoring/enforcement and dispute settlement procedures to be the best available proxies in the Bernauer et al. (2013a) data for the operationalization of our treaty legality variable. Each individual treaty characteristic, i.e., precisely stated obligations, monitoring/enforcement mechanisms, and dispute settlement procedures, was first coded as a binary variable. Specifically, obligation captures whether a treaty contains specific or not requirements pertaining to standards or goals to be achieved, or whether it quantifies standards or goals, for example in the form of specific emission targets. ${ }^{11}$ It is coded 1 if the treaty includes specific quantitative targets and 0 otherwise. Monitoring and enforcement indicates whether or not the treaty includes monitoring and enforcement provisions. ${ }^{12}$ Dispute settlement mechanism indicates whether an agreement includes dispute settlement procedures. ${ }^{13}$ Then, we characterize a treaty as being 'hard' when at least any two of these characteristics are present. ${ }^{14,15}$

\footnotetext{
${ }^{8}$ However, our results are robust to clustering the standard errors by either treaty or treaty-country combination (see online appendix).

9 Since it is, in some cases, debatable whether a particular treaty is indeed a global environmental treaty, we show in the online appendix that our results do not depend on how one defines a global environmental treaty ${ }^{10}$ The data is taken from Bernauer et al. (2013a). The coding instructions can be found in the online appendix and the dataset is available from the authors.

11 Although our measure of obligation is quite crude since it only accounts for rule precision rather than substantive commitments in terms of changes in behavior/policy, still we believe that it is able to capture the notion of loss of discretion to act in a self-serving manner and thus loss of sovereignty.

12 An example for a treaty with monitoring and enforcement provisions is the Kyoto Protocol since it specifies an institutional body to monitor and enforce the goals of the treaty, namely the Subsidiary Body for Implementation.

13 This variable is coded as one if the treaty text either outlines dispute settlement provisions for the specific treaty of if a third actor is responsible for solving potential disputes.

14 Our coding procedure follows Abbott et al. (2000) and Abbott and Snidal (2000) work, which distinguishes between 'hard' and 'soft' law according to three dimensions, namely obligation, precision, and delegation, and classifies as 'soft' law an agreement in which only one of the three elements is emphasized.

15 Of course, there exist other options. One option would be to use each characteristic separately as a dummy variable. However, the results then do not capture how a 'hard' treaty in general affects the ratification probability, which is what we want to model in this paper. Another option would be to use the
} 
To illustrate the coding of our 'hard' treaty measure, Table 1 shows the values of the individual treaty characteristics as well as the corresponding values for the 'hard' treaty measure for several well-known environmental treaties. For example, we see in Table 1 that the United Nations Framework Convention on Climate Change does not specify or quantify any clear standards that member countries need to achieve. Nor are there any monitoring and enforcement provisions intended to oversee member countries' actions on climate change. However, the convention contains clear guidance on how to proceed in the event of a dispute between member countries. If the parties fail to solve their dispute through negotiation, they are urged to submit the dispute to the International Court of Justice. However, since this is only one of the three characteristics that together make up a 'hard' treaty, the Framework Convention receives a zero on the aggregated 'hard' treaty variable.

In contrast, the Kyoto Protocol states clear emission reduction targets for those countries defined as Annex I. Furthermore, the Protocol specifies an institutional body to monitor and enforce the goals of the treaty with the establishment of the Subsidiary Body for Implementation. Since the Protocol also contains the same dispute settlement mechanism as the United Nations Framework Convention, it is coded as being a 'hard' treaty.

To capture the formal, constitutional requirements we rely on Hathaway's (2008) classification of constitutional requirements for treaty ratification. Hathaway provides data on whether: no legislative approval is required; majority in one house is required; majority in two houses is required; supermajority in one house is required; and supermajority in both houses is required.

We first combine these data and create a variable that captures whether legislative approval is needed or not in any of the two houses. In a second step, we distinguish whether legislative approval takes on the form of simple majority voting or requires for a supermajority in any of the two houses. ${ }^{16}$ Unfortunately, Hathaway only codes the constitutions of all countries in the year 2007. This implies that we do not have any variance over time, which is problematic especially for those countries that have experienced changes in their constitutional provisions. Since constitutional provisions rarely change, if at all, we feel quite confident that we can use these data. ${ }^{17}$

With regard to control covariates, we employ the variables suggested in Bernauer et al. (2010, 2013a). First, we include a country's Trade Openness measured as the ratio of the sum of exports and imports to GDP taken from the Penn World Tables (Heston et al. 2012) and its IGO membership taken from the Correlates of War Project (Pevehouse et al. 2004). Second, we use the Polity2 variable from the POLITY IV data set to measure political regime type (Democracy) (Marshall and Jaggers 2002). Third, a country's wealth is

Footnote 15 continued

sum of the three characteristics. Since the results are identical to the results presented in the paper using the dichotomous measure, we present them in the online appendix (see Table A.3). Finally, and most importantly, the findings are the same if we either use a 'hard' treaty measure that takes on the value of one as soon as one of the three characteristics are present or if we use a measure that becomes one only if all three characteristics are present (see table A.5 in the online appendix). These results indicate that the presence of any of the treaty characteristics is enough to deter ratification corroborating thus the findings reported by Bernauer et al. (2013a).

16 Another possibility would be to code whether none, only the lower, or both houses need to approve a treaty. We show results based on this coding in the online appendix in Table A.13.

17 To test the robustness of this measure, however, we run our models excluding all transition countries because these countries were the most likely to experience a constitutional reform. The exclusion of the transition countries from the analysis, however, does not alter our main results (see Table A.16 in the online appendix). 
Table 1 Examples of treaty institutional design coding

\begin{tabular}{|c|c|c|c|c|}
\hline & Obligation & $\begin{array}{l}\text { Monitoring } \\
\text { and } \\
\text { enforcement }\end{array}$ & $\begin{array}{l}\text { Dispute } \\
\text { settlement }\end{array}$ & $\begin{array}{l}\text { Hard } \\
\text { treaty }\end{array}$ \\
\hline $\begin{array}{l}\text { United Nations framework convention on climate } \\
\text { change }\end{array}$ & 0 & 0 & 1 & 0 \\
\hline $\begin{array}{l}\text { Kyoto protocol to the United Nations framework } \\
\text { convention on climate change }\end{array}$ & 1 & 1 & 1 & 1 \\
\hline $\begin{array}{l}\text { International convention to combat desertification in } \\
\text { those countries experiencing serious drought and/or } \\
\text { desertification }\end{array}$ & 1 & 0 & 1 & 1 \\
\hline Protocol on substances that deplete the ozone layer & 1 & 1 & 1 & 1 \\
\hline United Nations convention on the law of the sea & 1 & 0 & 1 & 1 \\
\hline Convention on the high seas & 0 & 0 & 0 & $\mathbf{0}$ \\
\hline $\begin{array}{l}\text { International convention for the prevention of pollution } \\
\text { from ships (MARPOL) }\end{array}$ & 1 & 0 & 1 & 1 \\
\hline International convention for the regulation of whaling & 1 & 0 & 0 & $\mathbf{0}$ \\
\hline $\begin{array}{l}\text { Convention on the conservation of migratory species of } \\
\text { wild animals }\end{array}$ & 0 & 0 & 1 & 0 \\
\hline
\end{tabular}

measured by the log of GDP per capita (Gleditsch 2002). ${ }^{18}$ Fourth, to control for contingent behavior effects, we include three variables: the total number of states in the international system, the percentage of countries from the same geographical group and from the same income group that have already ratified the treaty (\# of Countries Ratified, \% of Region Group Ratified region, and \% of Income Group Ratified, respectively). Fifth, we use the $\log$ of GDP, that is, the economic size of a country, to control for the effect of power (Gleditsch 2002). Sixth, we add the log of $\mathrm{SO}_{2}$ emissions per capita $\left(\mathrm{SO}_{2}\right.$ per capita), as this type of pollution is arguably the most common form of air pollution (Stern 2005). ${ }^{19}$ Sixth, we include a dummy variable indicating whether an agreement deals with a global public good or a national or sub-national public good (global public good vs domestic public good). ${ }^{20}$ Finally, we control for whether member countries are granted technological and/or financial assistance to meet the treaty's goals (technological and financial assistance). Table A.17 and A.18 in the online appendix show the descriptive statistics for all variables used in our analyses.

\footnotetext{
18 Following the literature on the Environmental Kuznets Curve one could expect income to have an inverted U-shaped effect on the likelihood of joining international environmental treaties. However, when we include the squared value of the log of GDP per capita we see that the effect is monotonically increasing with GDP per capita. To keep our model as parsimonious as possible we therefore opted to include only GDP per capita without its square term. Results including the squared term are available upon request.

19 It would be preferable to use a measure that covers a country's environmental quality in more general terms. Unfortunately, lack of data in time-series format limits our selection to $\mathrm{SO}_{2}$ emissions. For example, data on water quality exists only from the 1980s onwards whereas composite indices of environmental performance tend to be not comparable over time. Finally, we refrain from using $\mathrm{CO}_{2}$ emissions since $\mathrm{CO}_{2}$ is a global and not a local public good.

${ }^{20}$ Global public good refers to internationally or globally shared natural resources or ecosystems, such as climate change; domestic public good refers to national environmental public goods such as the conservation of domestic wildlife or natural habitats.
} 


\section{Results}

Table 2 reports the results testing hypotheses 1 and 2 . As postulated by hypothesis 1 , treaties that are characterized as 'hard' are indeed less likely to be ratified. This implies that countries seem to shy away from those treaties that are perceived to be challenging to their sovereignty. This result is in line with several empirical studies in the fields of human rights and environment (Bernauer et al. 2013a; Hathaway 2007; Goodliffe and Hawking 2006; Cole 2005, 2009). These studies find evidence that countries are less likely to ratify a human rights or environmental treaty if they have to change their human rights behavior as a consequence of the rules postulated by the treaty and/or if the treaty sets up monitoring and enforcement mechanisms.

With regard to hypothesis 2, we observe that countries with high constitutional requirements for treaty ratification are not less likely to ratify MEAs. Hence, in contrast to most existing studies and our hypothesis 2 , we do not find direct evidence that greater constitutional hurdles, and thus more potential veto points, hinders the ratification of multilateral environmental treaties (Bang et al. 2012; Fredriksson et al. 2007; Tsebelis 2002; Rosendorff and Milner 2001). However, if we distinguish between countries that require supermajority and countries that require simple majority only, the results show that approval with supermajority is indeed a hindrance to treaty ratification (model 2 in Table 2). ${ }^{21}$ These findings thus offer some support to hypothesis 2 linking more stringent formal, constitutional requirements to a lower probability of treaty ratification.

Concerning the control variables, we see that neither IGO membership nor the fact whether countries are economically better integrated into the world economy, in the sense that they trade more, affects treaty ratification. In contrast, democratic countries tend to join more treaties than autocratic countries do. Similarly, richer countries and countries with higher $\mathrm{SO}_{2}$ emissions are also significantly more likely to ratify MEAs as are more powerful countries.

Contingent behavior also plays an important role in explaining the likelihood of treaty ratification: the more countries in general and the more countries in a country's region that have ratified a particular treaty increase the likelihood of treaty ratification. In contrast, the number of countries in a country's income group does not encourage but discourages other countries from ratifying the same treaty. Finally, we observe that treaty special provisions and characteristics are also significantly related to the likelihood of ratifying MEAs. While treaties containing provisions for technical assistance either to all or to developing countries only are more often ratified, treaties dealing with global public goods are less likely to be ratified. ${ }^{22}$

To illustrate the effect size of the different variables, Table 3 reports the predicted probabilities for each variable while holding all other variables at their mean value. The first column of Table 3 shows changes in probabilities of treaty ratification if the explanatory variable under consideration changes its value from the mean to the maximum.

\footnotetext{
21 We show in the online appendix that this effect is not only due to the US.

22 It is also important to note that these results are not driven by whether the treaty allows for differentiated obligations for a subset of countries (e.g., lower emission targets for developing countries), see Table A.6. Furthermore, the results do not change if we use several dummy variables to control for treaties dealing with specific issue such as pollution, species, nuclear, and habitat; treaties dealing with agricultural issues serve as the baseline category (see Table A.19).
} 
Table 2 Main results

\begin{tabular}{|c|c|c|}
\hline & $\begin{array}{l}\text { (1) } \\
\text { Logit regression }\end{array}$ & $\begin{array}{l}\text { (2) } \\
\text { Logit regression }\end{array}$ \\
\hline Hard treaty & $\begin{array}{l}-0.27 * * * \\
(0.035)\end{array}$ & $\begin{array}{l}-0.27 * * * \\
(0.035)\end{array}$ \\
\hline Legislative approval & $\begin{array}{l}0.17 \\
(0.121)\end{array}$ & \\
\hline Legislative approval: majority & & $\begin{array}{l}0.18 \\
(0.120)\end{array}$ \\
\hline Legislative approval: supermajority & & $\begin{array}{l}-0.39^{* *} \\
(0.184)\end{array}$ \\
\hline ln trade openness & $\begin{array}{l}0.04 \\
(0.079)\end{array}$ & $\begin{array}{l}0.04 \\
(0.078)\end{array}$ \\
\hline IGO membership & $\begin{array}{l}-0.00 \\
(0.003)\end{array}$ & $\begin{array}{l}-0.00 \\
(0.003)\end{array}$ \\
\hline Polity & $\begin{array}{l}0.02^{* * * *} \\
(0.006)\end{array}$ & $\begin{array}{l}0.02 * * * \\
(0.006)\end{array}$ \\
\hline $\ln$ GDP pc & $\begin{array}{l}0.12 * * \\
(0.058)\end{array}$ & $\begin{array}{l}0.13 * * \\
(0.057)\end{array}$ \\
\hline $\ln \mathrm{SO}_{2} \mathrm{pc}$ & $\begin{array}{l}0.07 * * \\
(0.032)\end{array}$ & $\begin{array}{l}0.07 * * \\
(0.032)\end{array}$ \\
\hline Number of countries ratified & $\begin{array}{l}0.02 * * * \\
(0.002)\end{array}$ & $\begin{array}{l}0.02 * * * \\
(0.002)\end{array}$ \\
\hline Number of countries in same income group & $\begin{array}{l}-0.00 \\
(0.003)\end{array}$ & $\begin{array}{l}-0.00 \\
(0.003)\end{array}$ \\
\hline Number of countries in same region & $\begin{array}{l}0.03 * * * \\
(0.002)\end{array}$ & $\begin{array}{l}0.03 * * * \\
(0.002)\end{array}$ \\
\hline $\ln$ GDP & $\begin{array}{l}0.12^{* * * *} \\
(0.033)\end{array}$ & $\begin{array}{l}0.13 * * * \\
(0.033)\end{array}$ \\
\hline Assistance & $\begin{array}{l}0.30^{* * * *} \\
(0.047)\end{array}$ & $\begin{array}{l}0.30^{* * * *} \\
(0.047)\end{array}$ \\
\hline Assistance developing countries & $\begin{array}{l}0.55^{* * * *} \\
(0.081)\end{array}$ & $\begin{array}{l}0.55^{* * *} \\
(0.081)\end{array}$ \\
\hline Global public good & $\begin{array}{l}-0.55 * * * \\
(0.043)\end{array}$ & $\begin{array}{l}-0.55 * * * \\
(0.044)\end{array}$ \\
\hline Mixed global public good & $\begin{array}{l}-0.38 * * * \\
(0.054)\end{array}$ & $\begin{array}{l}-0.38 * * * \\
(0.054)\end{array}$ \\
\hline$t$ & $\begin{array}{l}-0.32 * * * \\
(0.016)\end{array}$ & $\begin{array}{l}-0.32 * * * \\
(0.016)\end{array}$ \\
\hline$t 2$ & $\begin{array}{l}0.01 * * * \\
(0.001)\end{array}$ & $\begin{array}{l}0.01 * * * \\
(0.001)\end{array}$ \\
\hline$t 3$ & $\begin{array}{l}-0.00 * * * \\
(0.000)\end{array}$ & $\begin{array}{l}-0.00 * * * \\
(0.000)\end{array}$ \\
\hline Constant & $\begin{array}{l}-6.46^{* * * *} \\
(1.049)\end{array}$ & $\begin{array}{l}-6.84 * * * \\
(1.059)\end{array}$ \\
\hline Log likelihood & $-26,008.397$ & $-25,984.018$ \\
\hline
\end{tabular}


Table 2 continued

\begin{tabular}{lll}
\hline & $(1)$ & $(2)$ \\
& Logit regression & Logit regression \\
\hline Pseudo $R 2$ & 0.19 & 0.19 \\
Observations & 538,036 & 538,036 \\
\hline
\end{tabular}

Robust standard errors in parentheses, clustered at country level

$* * * p<0.01 ; * * p<0.05 ; * p<0.10$

Table 3 Simulated probabilities (based on Model 2 in Table 2)

\begin{tabular}{lrrr}
\hline Simulated probability & Mean to max & Min to mean & \multicolumn{1}{c}{ Min to max } \\
$P r($ ratification = 1) & & & $-0.001(0.000)$ \\
\hline Hard treaty & & & $0.001(0.000)$ \\
Legislative approval: majority & & $-0.001(0.000)$ \\
Legislative approval: supermajority & & $0.001(0.000)$ \\
Assistance & & & $0.003(0.001)$ \\
Assistance developing countries & & & $-0.002(0.000)$ \\
Global public goods & & & $-0.001(0.000)$ \\
Mixed global public good & $0.001(0.000)$ & $0.001(0.000)$ & $0.002(0.001)$ \\
Polity & $0.000(0.001)$ & $0.000(0.001)$ & $0.000(0.000)$ \\
ln trade openness & $-0.000(0.000)$ & $-0.000(0.000)$ & $-0.000(0.000)$ \\
IGO membership & $0.100(0.037)$ & $0.001(0.000)$ & $0.100(0.037)$ \\
Number of other countries that ratified & $-0.001(0.001)$ & $-0.000(0.000)$ & $-0.001(0.001)$ \\
Percent of same income group that ratified & $0.081(0.016)$ & $0.001(0.000)$ & $0.082(0.016)$ \\
Percent of countries in region that ratified & $0.002(0.001)$ & $0.001(0.000)$ & $0.003(0.001)$ \\
ln GDP per capita & $0.005(0.002)$ & $0.002(0.000)$ & $0.007(0.002)$ \\
ln GDP & $0.002(0.001)$ & $0.002(0.001)$ & $0.004(0.002)$ \\
ln SO ${ }_{2}$ per capita & & & \\
\hline
\end{tabular}

Standard errors in parentheses; all other variables are kept at their mean values

Columns 2 and 3 indicate changes in the propensity of treaty ratification for changes of the explanatory variable from the minimum to the mean, and from the minimum to the maximum, respectively. Two of the three variables measuring contingent behavior (the more countries in general and the more countries in a country's region that have ratified a particular treaty) have the biggest effect size when varying from their minimal to their maximal level. For example, if we compare a treaty which the average number of countries has ratified with a treaty that the maximum number of countries has ratified, we observe that the likelihood of ratification for any additional country increases by about $10 \%$.

All other variables are similar with regard to the magnitude of their effect. For example, if we compare a 'hard' treaty to a 'soft' treaty, the probability of ratification decreases by $0.1 \%$. While this seems to be a low number, one needs to bear in mind that observing a value of 1 in our dataset is actually a rare event. In $<1 \%$ of the country-treaty years, the dependent variable takes on the value 1 indicating that a given country has ratified a 


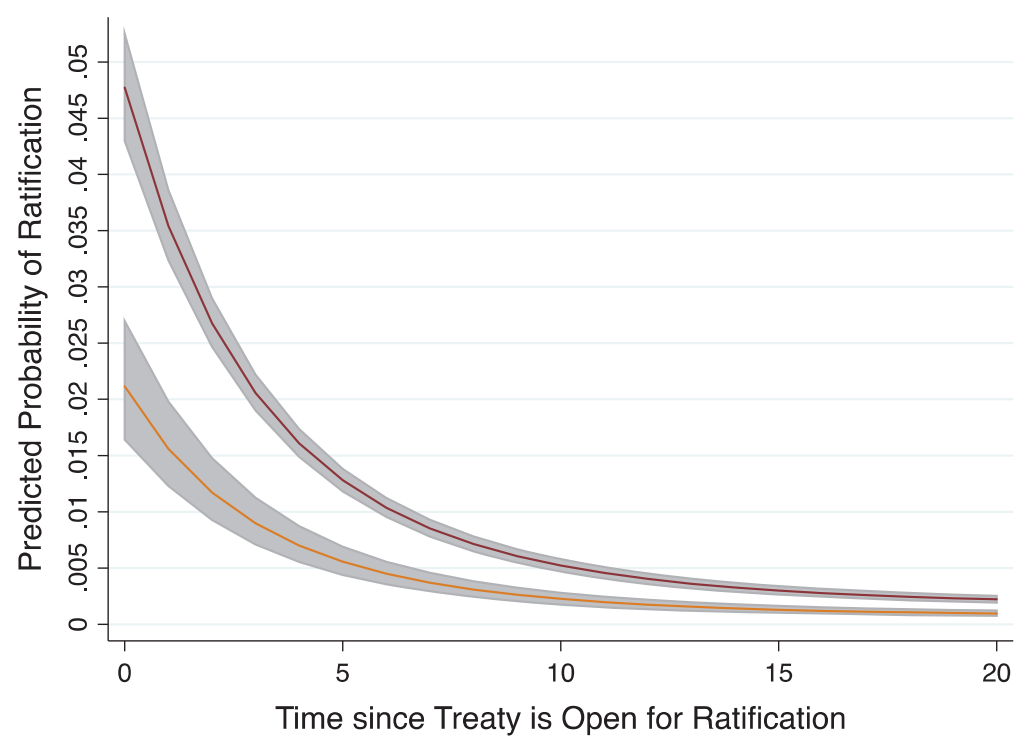

Fig. 1 Predicted probabilities of treaty ratification. Yellow line predicted probability of treaty ratification given a 'hard' treaty and supermajority is requested for ratification while holding all other variables at their median value. Red line predicted probability of treaty ratification given a 'soft' treaty and simple majority is requested for ratification while holding all other variables at their median value. Gray area $95 \%$ confidence interval. (Color figure online)

particular treaty in this year. Hence by construction of our dataset, predicted probabilities of observing ratification need to be rather small. ${ }^{23}$

To further illustrate the effect sizes of our two key independent variables, we plotted the likelihood of treaty ratification over a time span of 20 years for two different combinations of treaty legality and domestic constitutional hurdles while holding all other variables at their median values.

The yellow line in Fig. 1 displays the predicted probability of treaty ratification given a 'hard' treaty and given that a supermajority is required for its ratification. In contrast, the red line displays the predicted probability of treaty ratification given a 'soft' treaty and given that only a simple majority is required for its ratification. Hence, the red line characterizes a situation that should be, according to our theory, conducive to ratification, while the yellow line represents a situation that should be detrimental for ratification. And indeed, as can be seen in Fig. 1, not only does the yellow line lie significantly below the red line over the whole time span plotted in the figure, the predicted probability for treaty ratification more than doubles if we move from the detrimental scenario- 'hard' treaty and supermajority (yellow line)— to the conducive scenario—'soft' treaty and simple majority (red line).

\section{Conclusion}

The failure of US Congress to ratify the Kyoto Protocol on climate change mitigation has led to renewed scholarly interest in the conditions under which states join international agreements, and in particular multilateral environmental agreements. We study the effects

${ }^{23}$ However, if we look at the percentage change of the odds of observing a positive outcome, the picture changes dramatically. For example, a change from a 'soft' to a 'hard' treaty decreases the odds of ratifying a given treaty by almost $24 \%$ (see table A.15 in the online appendix). 
of two key factors, namely treaty legality and domestic constitutional hurdles, on the ratification behavior of states with respect to MEAs. In doing so, we differ from existing studies in that we examine the impact of treaty characteristics and domestic institutions on ratification behavior alongside the already more extensively studied determinants of cooperation, such as interdependency effects, trade openness, regime type, and national income. By treaty legality, we mean the degree to which a treaty prescribes precisely stated obligations, and the existence of monitoring, enforcement, and dispute resolution mechanisms. Domestic institutional hurdles refer to the constitutional requirements for treaty ratification.

Specifically, we argue that high treaty requirements in the form of precisely stated obligations, strong monitoring/enforcement mechanisms, and delegation of authority to a dispute resolution body as well as high domestic constitutional hurdles such as requirements for explicit legislative approval should deter countries from ratifying a treaty.

To test our theoretical arguments, we use a new time-series-cross-sectional dataset that includes information on the ratification behavior of 160 countries as well as treaty characteristics with respect to 220 multilateral environmental agreements in the period 1950-2000.

Controlling for various incentives emanating from treaties dealing with domestic versus global public goods as well as economic development, political system, trade, and the behavior of other (peer) countries, we find that treaties which we defined as 'hard' treaties deter ratification. This finding supports our argument that more legalized treaties are considered to be more costly in terms of sovereignty loss for their member countries (Abbott and Snidal 2000; Abbott et al. 2000; Downs et al. 1996). With regard to a country's domestic constitutional hurdles, we observe that the form of legislative approval needed for ratification seems to matter. But whereas general legislative approval has no significant effect, approval requiring a supermajority clearly decreases the likelihood of environmental treaty ratification. This is in line with the argument that the more demanding the legislative approval becomes the more difficult it gets to obtain broader consent among legislators with diverse preferences to ratify a particular treaty (Bang et al. 2012; Tsebelis 2002). In this respect, it would be interesting to analyze whether more detailed legislative requirements, such as the consent of regional bodies or courts as can sometimes be found in democratic countries, further lower the chances of treaty ratification

In this paper, we focus on the ratification behavior of MEAs because we believe that 'hard' treaties constrains are likely to play a much larger role in environmental agreements than in other issue areas such as trade and finance. The main reason is that since treaty participants cannot punish each other for treaty violations via non-cooperative behavior (i.e., if you pollute, I will pollute more), treaty characteristics such as monitoring and enforcement provisions play a very important role in conditioning ratification of environmental treaties. Hence, we expect that our analysis could apply equally to human rights treaties but probably less to treaties where reciprocal sanctioning is more feasible.

\section{References}

Abbott, K. W., Keohane, R., Moravcsik, A., Slaughter, A.-M., \& Snidal, D. (2000). The concept of legalization. International Organization, 54(3), 401-419.

Abbott, K. W., \& Snidal, D. (2000). Hard and soft law in international governance. International Organization, 54(3), 421-456. 
Bang, G., Hovi, J., \& Sprinz, D. F. (2012). US presidents and the failure to ratify multilateral environmental agreements. Climate Policy, 12(6), 755-763.

Barrett, S. (1994). Self-enforcing international environmental agreements. Oxford Economic Papers, 46, 878-894.

Barrett, S. (1998). On the theory and diplomacy of environmental treaty-making. Environmental and Resource Economics, 11(3-4), 317-333.

Barrett, S. (2006). Environment and statecraft: The strategy of environmental treaty-making. New York: Oxford University Press.

Bernauer, T., Böhmelt, B., \& Koubi, V. (2013a). Is there a democracy-civil society paradox in global environmental governance? Global Environmental Politics, 13(1), 88-107.

Bernauer, T., Kalbhenn, A., Koubi, V., \& Spilker, G. (2010). A comparison of international and domestic sources of global governance dynamics. British Journal of Political Science, 40(3), 509-538.

Bernauer, T., Kalbhenn, A., Koubi, V., \& Spilker, G. (2013b). Is there a depth versus participation' dilemma in international cooperation? Review of International Organizations, 8(4), 477-497.

Beron, K. J., Murdoch, J. C., \& Vijverberg, W. P. M. (2003). Why cooperate? Public goods, economic power, and the Montreal Protocol. The Review of Economics and Statistics, 85(2), 286-297.

Böhmelt, T., \& Pilster, U. H. (2010). International environmental regimes: Legalisation, flexibility and effectiveness. Australian Journal of Political Science, 45(2), 245-260.

Boockmann, B., \& Thurner, P. W. (2006). Flexibility provisions in multilateral environmental treaties. International Environmental Agreements: Politics, Law and Economics, 6(2), 113-135.

Carter, D. B., \& Signorino, C. S. (2010). Back to the future: Modeling time dependence with binary data. Political Analysis, 18(2), 271-292.

Center for International Earth Science and Information Network (CIESIN), Columbia University. (2005). Environmental Treaties and Resource Indicators (ENTRI) Query Service. http://sedac.ciesin.columbia. edu/entri/.

Chayes, A., \& Chayes, A. (1993). On compliance. International Organization, 47(2), 175-205.

Chinkin, C. M. (1989). The challenge of soft law: Development and change in international law. International and Comparative Law Quarterly, 38(4), 850-866.

Cole, W. M. (2005). Sovereignty relinquished? Explaining commitment to the international human rights covenants, 1969-1999. American Sociological Review, 70(3), 472-495.

Cole, W. M. (2009). Hard and soft commitments to human rights treaties, 1966-2000. Sociological Forum, 24(3), 563-588.

Congleton, R. (1992). Political institutions and pollution control. The Review of Economics and Statistics, 74(3), 412-421.

Downs, G. W., Rocke, D. M., \& Barsoom, P. N. (1996). Is the good news about compliance good news for cooperation? International Organization, 52(3), 379-406.

Finus, M. (2001). Game theory and international environmental cooperation. Cheltenham: Edward Elgar.

Fredriksson, P. G., \& Gaston, N. (2000). Ratification of the 1992 climate change convention: What determines legislative delay? Public Choice, 104(3-4), 345-368.

Fredriksson, P. G., Neumayer, E., \& Ujhelyi, G. (2007). Kyoto Protocol cooperation: Does government corruption facilitate environmental lobbying? Public Choice, 133, 231-251.

Fredriksson, P. G., \& Ujhelyi, G. (2006). Political institutions, interest groups, and the ratification of international environmental agreements. Working Paper. Houston, TX: Department of Economics: University of Houston.

Gleditsch, K. S. (2002). Expanded trade and GDP data. Journal of Conflict Resolution, 46(5), 712-724.

Goodliffe, J., \& Hawkins, D. (2006). Explaining commitment: States and the convention against torture. Journal of Politics, 68(2), 358-371.

Guzman, A. T. (2002). The cost of credibility: Explaining resistance to interstate dispute resolution mechanisms. Journal of Legal Studies, XXXI, 303-326.

Guzman, A. T. (2005). The design of international agreements. The European Journal of International Law, 16(4), 579-612.

Hathaway, O. A. (2007). Why do countries commit to human rights treaties? Journal of Conflict Resolution, 51(4), 588-621.

Hathaway, O. A. (2008). Treaties' end: The past, present and future of international lawmaking in the United States. The Yale Law Journal, 117(7), 1236-1372.

Heston, A., Summers, R., \& Aten, B. (2012). Penn world table. (version 7.1), Center for International Comparisons of Production, Income and Prices at the University of Pennsylvania.

Koremenos, B. (2001). Loosening the ties that bind: A learning model of agreement flexibility. International Organization, 55(2), 289-325. 
Koremenos, B. (2005). Contracting around international uncertainty. American Political Science Review, 99(4), 549-565.

Koremenos, B., Lipson, C., \& Snidal, D. (2001). The rational design of international institutions. International Organization, 55(4), 761-799.

Lipson, C. (1991). Why are some international agreements informal? International Organization, 45(4), 495-538.

Marshall, M. G., \& Jaggers, K. (2002). Polity IV project: Political regime characteristics and transitions, 1800-2002. http://www.systemicpeace.org/polity/polity4.htm.

Martin, L. (2000). Democratic commitments: Legislatures and international cooperation. Princeton, NJ: Princeton University Press.

Milner, H. V. (1997). Interests, institutions, and information: Domestic politics and international relations. Cambridge: Cambridge University Press.

Milner, H. V., \& Rosendorff, P. B. (1997). Democratic politics and international trade negotiations: Elections and divided government as constraints on trade liberalization. Journal of Conflict Resolution, 41(1), 117-146.

Mitchell, R. B. (2002). International environmental agreements database project (version 2007.1). http:// iea.uoregon.edu/.

Neumayer, E. (2002a). Do democracies exhibit stronger international environmental commitment? A crosscountry analysis. Journal of Peace Research, 39(2), 139-164.

Neumayer, E. (2002b). Does trade openness promote multilateral environmental cooperation? World Economy, 25(6), 815-832.

Perrin, S., \& Bernauer, T. (2010). International regime formation revisited: Explaining ratification behavior with respect to long range transboundary air pollution agreements. European Union Politics, 11(3), 405-426.

Pevehouse, J. C., Nordstrom, T., \& Warnke, K. (2004). The COW-2 international organizations dataset version 2.0. Conflict Management and Peace Science, 21(2), 101-119.

Raustiala, K. (2005). Form and substance in international agreements. The American Journal of International Law, 99(3), 581-614.

Roberts, T. J., Park, B. C., \& Vasquez, A. A. (2004). Who ratifies environmental treaties and why? Institutionalism, structuralism and participation by 192 nations in 22 treaties. Global Environmental Politics, 4(3), 22-64.

Rosendorff, P. B. (2005). Stability and rigidity: Politics and design of the WTO's dispute settlement procedure. American Political Science Review, 99(3), 389-400.

Rosendorff, P. B., \& Milner, H. V. (2001). The optimal design of international trade institutions: Uncertainty and escape. International Organization, 55(4), 829-857.

Simmons, B. A. (1993). Credibility, costs, and institutions: Cooperation on economic sanctions. World Politics, 45(3), 406-432.

Simmons, B. A. (2000). International law and state behavior: Commitment and compliance in international monetary affairs. American Political Science Review, 94(4), 819-835.

Simmons, B. A. (2009). Mobilizing for human rights: International law in domestic politics. Cambridge: Cambridge University Press.

Smith, J. M. (2000). The politics of dispute settlement design: Explaining legalism in regional pacts. International Organization, 54(1), 137-180.

Stern, D. I. (2005). Global sulfur emissions from 1850 to 2000. Chemosphere, 58, 163-175.

Subramanian, N., \& Urpelainen, J. (2013). Addressing cross-border environmental displacement: When can international treaties help?. International Environmental Agreements: Politics, Law and Economics. doi:10.1007/s10784-013-9233-2.

Tsebelis, G. (2002). Veto players: How political institutions work. Princeton: Princeton University Press.

von Stein, J. (2008). The international law and politics of climate change. Journal of Conflict Resolution, 52(2), 243-268.

Wangler, L., Altamirano-Cabrera, J.-C., \& Weikard, H.-P. (2013). The political economy of international environmental agreements: A survey. International Environmental Agreements: Politics, Law and Economics, 13, 387-403.

Yamagata, Y., Yang, J., \& Galaskiewicz, J. (2013). A contingency theory of policy innovation: How different theories explain the ratification of the UNFCCC and Kyoto Protocol. International Environmental Agreements: Politics, Law and Economics, 13, 251-270. 